\title{
SPOSOBY INICJOWANIA POSTĘPOWANIA PRYWATNOSKARGOWEGO
}

\section{Wprowadzenie}

Mając na względzie wszechobecne postulaty dotyczące konieczności uproszczenia postępowania karnego oraz odciążenia organów wymiaru sprawiedliwości, jako uzasadnione jawi się możliwie najczęstsze stosowanie przepisów o postępowaniach szczególnych. Ratio legis tych postępowań przejawia się bowiem właśnie $\mathrm{w}$ uproszczeniu procedury orzekania w przedmiocie odpowiedzialności karnej oskarżonego w stosunku do wymogów trybu zwyczajnego. Jednym z kodeksowych postępowań szczególnych jest postępowanie w sprawach z oskarżenia prywatnego, które zasadniczo inicjowane jest przez pokrzywdzonego i w pewnej mierze pozostaje przez niego prowadzone. Pomimo uproszczenia inicjowania ww. postępowania do niezbędnego minimum, procedura jego wszczęcia może stanowić podstawę problemów natury faktycznej oraz prawnej. Dlatego też w niniejszym opracowaniu zostaną przedstawione dwie instytucje postępowania prywatnoskargowego - dwa sposoby jego wszczęcia: prywatny akt oskarżenia oraz ustna lub pisemna skarga złożona na policji. Są to możliwości równorzędne oraz od siebie niezależne, jednakże nie jest możliwe wykorzystanie obu w jednej sprawie, ponieważ wszczęcie postępowania na którykolwiek ze sposobów powoduje zawisłość sporu, stanowiącą negatywną przesłankę procesową (art. $17 \S 1$ pkt 7 k.p.k.).

Należy w tym miejscu podnieść, że oba sposoby wszczęcia postępowania prywatnoskargowego czynią zadość wymogom zasady skargowości

* Mgr, doktorant Katolickiego Uniwersytetu Lubelskiego Jana Pawła II; e-mail: markiewicz.tymon@gmail.com. 
(art. $14 \S 1$ k.p.k.). Skuteczne wniesienie prywatnego aktu oskarżenia do sądu lub złożenie ustnej lub pisemnej skargi na policji powoduje brak możliwości umorzenia postępowania $\mathrm{z}$ uwagi na negatywną przesłankę procesową w postaci braku skargi uprawnionego oskarżyciela (art. $17 \S 1$ pkt 9 k.p.k.). Jak słusznie podnosi E. Kruk, zasada skargowości ma w ramach postępowania w sprawach z oskarżenia prywatnego wyraz szczególny, albowiem konieczność dokonania impulsu procesowego dla zaistnienia postępowania prywatnoskargowego została oddana $\mathrm{w}$ ręce pokrzywdzonego' ${ }^{1} \mathrm{~W}$ odniesieniu do skutecznego wniesienia skargi należy wskazać, że skarga musi zostać skutecznie wniesiona przez podmiot uprawniony, a więc przez pokrzywdzonego lub podmioty mogące wykonywać jego prawa. Co interesujące, a niewynikające wprost z przepisów postępowania karnego, rodzic małoletniego nie może, działając $w$ charakterze przedstawiciela ustawowego, wykonywać praw tego małoletniego jako pokrzywdzonego w postępowaniu karnym, w tym także w postępowaniu z oskarżenia prywatnego, jeżeli oskarżonym jest drugi z rodziców ${ }^{2}$. Takie zawężenie kręgu podmiotów uprawnionych do wniesienia skargi wynika ze stosowania, na podstawie wykładni systemowej, przepisów prawa rodzinnego.

\section{Prywatny akt oskarżenia}

Pismem procesowym inicjującym postępowanie prywatnoskargowe jest prywatny akt oskarżenia. Ze względu na brak przymusu adwokacko-radcowskiego oraz okoliczności faktyczne, w których zasadniczo wnoszący prywatny akt oskarżenia pokrzywdzony nie jest podmiotem profesjonalnego obrotu prawnego, wymogi formalne tego pisma procesowego zostały ograniczone do minimum. Oprócz podstawowych wymogów pisma procesowego z art. 119 k.p.k. (czyli oznaczenie organu, do którego pismo jest kierowane, oznaczenie podmiotu wnoszącego pismo, data i podpis podmiotu wnoszącego pismo), prywatny akt oskarżenia może ograniczyć się do oznaczenia osoby oskarżonego, zarzucanego mu czynu oraz wskazania dowodów, na których opiera się oskarżenie (art. 487 k.p.k.). Ponadto, art. $621 \S 1$ k.p.k. obliguje oskarżyciela prywatnego do pokrycia zryczałtowanej równowartości wydatków. Zgodnie z Rozporządzeniem Ministra Sprawiedliwości w sprawie wysokości zryczałtowanej równowartości wy-

\footnotetext{
1 Zob. E. Kruk, Skarga w postępowaniu prywatnoskargowym, „Ius Novum” 2012, nr 4, s. 78.

2 Uchwała Sądu Najwyższego z dnia 30 września 2010 r., I KZP 10/10, OSNWK 2010, nr 10, poz. 84 .
} 
datków w sprawach z oskarżenia prywatnego ${ }^{3}$ kwota, którą oskarżyciel prywatny jest zobowiązany uiścić wynosi 300 zł.

W przypadku niedopełnienia wymogów formalnych wzywa się osobę, od której pochodzi prywatny akt oskarżenia, do uzupełnienia braków formalnych w trybie art. 120 k.p.k. Nie ma tu zastosowania szczególna procedura przewidziana dla zwyczajnego aktu oskarżenia lub subsydiarnego aktu oskarżenia, do którego stosuje się odpowiednio przepisy o zwykłym akcie oskarżenia, tj. procedura z art. 337 k.p.k., co uzasadnione jest szczególnym charakterem i odmiennymi wymogami prywatnego aktu oskarżenia, a także praktycznym brakiem możliwości realizacji tej procedury ze względu na zasadę nie prowadzenia typowego postępowania przygotowawczego w sprawach o przestępstwa ścigane z oskarżenia prywatnego. Nieuzupełnienie tych braków w terminie siedmiu dni skutkuje uznaniem prywatnego aktu oskarżenia za bezskuteczny, natomiast skuteczne ich uzupełnienie wywołuje skutki procesowe $z$ dniem jego pierwotnego wniesienia (art. 120 § 2 k.p.k.). Należy zastrzec, że wezwanie oskarżyciela prywatnego do wskazania innych elementów, niż wymienione w art. 487 k.p.k. w zw. z art. 119 § 1 k.p.k., np. wezwanie do wskazania podstawy prawnej czynu zarzucanego oskarżonemu, nie jest możliwe, przede wszystkim ze względu na fakt naruszenia $\mathrm{w}$ takiej sytuacji gwarantowanego w demokratycznym państwie prawa dostępu do wymiaru sprawiedliwości ${ }^{4}$. Takie wezwanie stanowiłoby zastosowanie wykładni rozszerzającej, która - w myśl zasady exceptiones non sunt excendende - nie może mieć zastosowania do przepisu o charakterze wyjątku, jakim jest przepis art. 487 k.p.k. Natomiast w kontekście wymogu konieczności wskazania dowodów, na których opiera się oskarżenie, interesującą konstrukcję przyjął Sąd Okręgowy w Tarnowie, który uznał, że niedopełnienie tego wymogu może wpływać jedynie na ocenę zasadności oskarżenia, ale nie może uzasadniać uznania aktu oskarżenia za bezskuteczny z powodu jego braków formalnych. Zdaniem sądu nie jest to brak formalny powodujący, że pismo procesowe w postaci prywatnego aktu oskarżenia nie może otrzymać dalszego biegu, gdy spełnia pozostałe kryteria wymienione $\mathrm{w}$ art. 487 k.p.k. oraz w art. 119 § 1 k.p.k. ${ }^{5}$ Jest to pogląd dyskusyjny. Należy wskazać na pewną jego słuszność w oparciu o istotę postępowania dowodowego, którego celem jest potwierdzenie okoliczności sprawy i uczynienie z nich

3 Rozporządzenie Ministra Sprawiedliwości z dnia 28 maja 2003 r. w sprawie wysokości zryczałtowanej równowartości wydatków w sprawach z oskarżenia prywatnego, Dz. U. z 2003 r. Nr 104, poz. 980.

4 Postanowienie Sądu Okręgowego w Tarnowie z dnia 2 sierpnia 2005 r., II Kz 157/05, KZS 2005, z. 9, poz. 63.

5 Postanowienie Sądu Okręgowego w Tarnowie z dnia 2 października 2007 r., II Kz 232/07, KZS 2007, z. 11, poz. 74. 
faktycznej podstawy rozstrzygnięcia, jednakże - w ocenie autora - nie jest on możliwy do zaakceptowania na gruncie wykładni systemowej i spojrzenia na uregulowania dotyczące prywatnego aktu oskarżenia w sposób całościowy. Wskazanie w tej skardze zasadniczej dowodów, na których opiera się oskarżenie, stanowi dla sądu, w chwili wszczęcia postępowania, jedyną podstawę faktyczną do rozpoznania sprawy. Brak tego wskazania powoduje formalny brak możliwości rozpoznania sprawy z uwagi przykładowo na brak możliwości wstępnej kontroli oskarżenia (procedowanie na podstawie art. 339 k.p.k.), a także brak podstaw do merytorycznego rozpoznania sprawy. Komentatorzy Kodeksu postępowania karnego zgodnie określają wskazanie dowodów, na których opiera się oskarżenie, za wymóg formalny prywatnego aktu oskarżenia ${ }^{6}$. R.A. Stefański dopuszcza jedynie możliwość, ażeby wskazania ww. dowodów dokonać nie w petitum prywatnego aktu oskarżenia, ale w jego uzasadnieniu?.

W odniesieniu do prawidłowego sformułowania aktu oskarżenia należy także zwrócić uwagę na stopień określoności oznaczenia oskarżonego. Z uwagi na względy gwarancyjne można zgodzić się ze stanowiskiem K. Eichstaedta, że zawarte w art. 487 k.p.k. sformułowanie „,akt oskarżenia może ograniczyć się do oznaczenia osoby oskarżonego" należy rozumieć w ten sposób, że wystarczające jest podanie imienia i nazwiska oskarżonego, natomiast w sformułowaniu "oznaczenie osoby oskarżonego" nie mieści się konieczność podania jego miejsca zamieszkania ${ }^{8}$. Należy podnieść, że istnieją w doktrynie procesu karnego poglądy przeciwne, skupiające się wokół konieczności wskazania adresu do doręczeń oskarżonego9. Wydaje się jednak zasadnym, żeby z uwagi na brak pełnych danych osobowych oskarżonego nie blokować pokrzywdzonemu możliwości rozpoznania sprawy prywatnoskargowej i uznać za dopuszczalną możliwość niedookreślania ww. adresu, a w konsekwencji doprowadzić do uzupełnienia tej informacji np. w trybie art. $488 \S 2$ k.p.k. Informacja znajdująca się w prywatnym akcie oskarżenia musi jednak spełniać przynajmniej minimalne kryteria oznaczenia osoby, a więc zawierać co najmniej imię i nazwisko lub inne dane

6 W ten sposób m.in. J. Grajewski, S. Steinborn, Komentarz aktualizowany do art. 487 Kodeksu postępowania karnego, LEX nr 470173, t. 3; T. Grzegorczyk, Komentarz do art. 487 Kodeksu postępowania karnego, LEX nr 70359, t. 2; R.A. Stefański, Komentarz do art. 487 Kodeksu postepowania karnego, t. 1, LEX nr 69644.

7 Zob. R.A. Stefański, Komentarz do art. 487 Kodeksu...

8 Zob. K. Eichstaedt, Art. 287, [w:] D. Świecki (red.), Kodeks postępowania karnego. Tom II. Komentarz aktualizowany, LEX/el 2018, t. 8.

9 O konieczności wskazania adresu zamieszkania, zob. T. Grzegorczyk, Kodeks postepowania karnego. Komentarz, Kraków 2005, s. 1188; o konieczności wskazania chociażby adresu miejsca pracy, zob. R.A. Stefański, Postępowanie w sprawach z oskarżenia prywatnego, [w:] Z. Gostyński (red.), Kodeks postępowania karnego. Komentarz, t. 3, Warszawa 2004, s. 399. 
pozwalające na chociażby względną identyfikację, a które to informacje stanowić będą podstawę określenia konkretnych danych we wskazanym trybie.

Istotna jest również zaskarżalność zarządzenia prezesa sądu (odpowiednio przewodniczącego wydziału lub upoważnionego sędziego) o uznaniu prywatnego aktu oskarżenia za bezskuteczny ze względu na nieuzupełnienie w odpowiednim terminie braków formalnych. Zdaniem (niewątpliwie słusznym) Sądu Najwyższego takie zarządzenie należy zakwalifikować jako zamykające drogę do wydania wyroku, więc na podstawie art. $459 \S 1$ k.p.k. w zw. z art. $466 \S 1$ k.p.k. przysługuje na nie zażalenie ${ }^{10}$.

Jako brak formalny prywatnego aktu oskarżenia należy kwalifikować także brak wpłaty zryczałtowanej równowartości wydatków. Potwierdził to Sąd Apelacyjny w Lublinie, który stwierdził, że nieuiszczenie zryczałtowanej równowartości wydatków i nieuzupełnienie tego braku w zakreślonym terminie oznacza zaistnienie negatywnej przesłanki procesowej z art. $17 \S 1$ pkt 9 k.p.k., czyli brak skargi uprawnionego oskarżyciela ${ }^{11}$. Usunięcie braku fiskalnego może nastąpić na dwa sposoby: oczywiście przez zapłatę albo przez złożenie wniosku o zwolnienie go od ponoszenia kosztów sądowych w całości lub części ze względu na sytuację rodzinną, majątkową i wysokość dochodów, które pozwalają uznać uiszczenie zryczałtowanej równowartości wydatków za zbyt uciążliwe dla niego. Sytuację rodzinną, majątkową i wysokość dochodów należy odpowiednio wykazać przez złożenie stosownych dokumentów ${ }^{12}$.

Między prywatnym aktem oskarżenia a zwykłym aktem oskarżenia istnieją nie tylko różnice, ale również podobieństwa. Przede wszystkim prywatny akt oskarżenia musi przyjąć formę oskarżenia, czyli opisać czyn (zdarzenie historyczne), z jakiego oskarżyciel wysnuwa możliwość realizacji znamion określonego typu czynu zabronionego, a także przedstawić dowody, które uzasadniają oskarżenie. $W$ tej perspektywie rola tego rodzaju dokumentu jest tożsama z prokuratorskim aktem oskarżenia - musi on dawać podstawy do prowadzenia postępowania karnego o konkretny czyn, na podstawie wiarygodnych dowodów uprawdopodobniających tezy oskarżenia w wysokim stopniu13. Należy w tym miejscu zauważyć, że określone ogólnikowo zobowiązanie jedynie do oznaczenia czynu zarzucanego oskarżonemu nie zwalnia oskarżyciela prywatnego z obowiązku sprecyzowania tego czynu. Istotną

10 Postanowienie Sądu Najwyższego z dnia 20 lipca 2005 r., I KZP 22/05, OSNKW 2005, nr 9, poz. 73.

11 Postanowienie Sądu Apelacyjnego w Lublinie z dnia 28 lipca 1999 r., II AKz 181/99.

12 Zob. K. Eichstaedt, Postępowania szczególne w polskim procesie karnym, Warszawa 2010, s. 107.

13 Postanowienie Sądu Najwyższego z dnia 21 stycznia 2015 r., V KK 297/14, LEX nr 1652419. 
rolę przy odpowiednim opisie czynu może spełniać nieobligatoryjna pomoc profesjonalnego prawnika, ponieważ jego udział w sporządzaniu prywatnego aktu oskarżenia pozwoli sądowi orzekającemu zyskać pewność co do intencji oskarżyciela prywatnego i rzeczywistego stanu faktycznego ${ }^{14}$. Jako podobieństwo należy ponadto wskazać możliwość wniesienia przez oskarżonego odpowiedzi na akt oskarżenia. Jest to uprawnienie oskarżonego do złożenia oświadczenia w przedmiocie wniesionego przeciwko niemu aktu oskarżenia. Istnienie tej instytucji podyktowane jest urzeczywistnianiem zasady kontradyktoryjności procesu karnego oraz prawa do obrony. Jak wskazuje R.A. Stefański instytucja odpowiedzi na akt oskarżenia ma zastosowanie przy wniesieniu każdego rodzaju aktu oskarżenia, a więc ma także zastosowanie w sytuacji wniesienia prywatnego aktu oskarżenia ${ }^{15}$.

Akt oskarżenia wnosi się bezpośrednio do sądu właściwego do rozpoznania sprawy. Właściwość sądu ustala się na podstawie ogólnych przepisów o właściwości, zgodnie z odpowiednim stosowaniem do postępowań szczególnych, w kwestiach nieuregulowanych, przepisów o postępowaniu zwyczajnym. W sprawach z oskarżenia prywatnego właściwy rzeczowo będzie zasadniczo sąd rejonowy. Właściwość miejscową wyznacza miejsce popełnienia przestępstwa (art. $31 \S 1$ k.p.k.), ewentualnie reguły pomocnicze dotyczące właściwości (art. 31 i 32 k.p.k.).

Ponadto należy nadmienić, że skuteczne wniesienie do sądu prywatnego aktu oskarżenia przerywa bieg terminu przedawnienia karalności przestępstw ściganych z oskarżenia prywatnego, określony w art. $101 \S 2$ k.k. ${ }^{16}$, a więc terminu rocznego od czasu, gdy pokrzywdzony dowiedział się o osobie sprawcy przestępstwa, nie później jednak niż z upływem 3 lat od czasu jego popełnienia.

\section{Ustna lub pisemna skarga złożona na policji}

Chcąc odnieść omówiony prywatny akt oskarżenia do ustnej lub pisemnej skargi złożonej na policji, należy podnieść, iż na podstawie postanowienia Sądu Najwyższego z dnia 17 kwietnia 1997 r. ${ }^{17}$ wykształcił się kon-

14 Postanowienie Sądu Najwyższego z dnia 31 marca 2015 r., IV KK 3/15, LEX nr 1666903.

15 Zob. R.A. Stefański, Odpowiedź na akt oskarżenia, „Prokuratura i Prawo” 2005, nr 5, s. $43-45$.

16 Zob. A. Ważny [w:] A. Sakowicz (red.), Kodeks postępowania karnego. Komentarz, Warszawa 2016, s. 1011.

17 Postanowienie Sądu Najwyższego z dnia 17 kwietnia 1997 r., I KZP 4/97, Wokanda 1998, nr 1, s. 16. 
sekwentnie aprobowany pogląd, zgodnie z którym skarga jest pojęciem szerszym od prywatnego aktu oskarżenia, co więcej, cechuje ją mniejszy stopień formalizmu. Konsekwencją przyjęcia takiej koncepcji zróżnicowania pojęć „,skarga” i „prywatny akt oskarżenia” jest odmienność wymogów formalnych wskazanych możliwości zainicjowania postępowania. Daje temu wyraz przede wszystkim dopuszczalność niedookreślenia osoby sprawcy. Naturalne jest, że pokrzywdzony może nie znać dokładnych danych dotyczących sprawcy przestępstwa, a także, że może mieć trudności z ich ustaleniem. Niewątpliwie określenie tożsamości oraz miejsca zamieszkania sprawcy wskazanego przez pokrzywdzonego mieści się w ramach zabezpieczenia dowodów, które w razie potrzeby policja ma obowiązek przeprowadzić. Pogląd odmienny, nakazujący stosować odpowiednio przepisy dotyczące wymogów formalnych prywatnego aktu oskarżenia do skargi na policji, przedstawił D. Kala, jednakże pogląd ten nie spotkał się $\mathrm{z}$ aprobatą doktryny prawa karnego ${ }^{18}$. Odformalizowanie skargi prywatnej składanej na policji posiada dodatkowy walor w postaci umożliwienia inicjacji ścigania nawet takiemu pokrzywdzonemu, dla którego sporządzenie nawet prostego pisma procesowego stanowi problem ${ }^{19}$.

Przepis art. $488 \S 1$ k.p.k. odnosi się wprost do skargi złożonej na policji. Nie jest jednak niemożliwe, wnioskując a fortiori, ażeby złożyć taką skargę także do prokuratora. Nie ulega bowiem wątpliwości, że prokuratura jest organem, który w ramach postępowania karnego jest organem nadrzędnym względem policji. Nie ulega także wątpliwości, że główne zadania prokuratury polegają na ściganiu przestępstw i strzeżeniu praworządności, zgodnie $\mathrm{z}$ art. 2 ustawy Prawo o prokuraturze ${ }^{20}$. Wydaje się więc uzasadnionym aby stwierdzić, że $w$ zakresie ścigania przestępstw, w tym przestępstw prywatnoskargowych, prokuratura dysponuje co najmniej takimi samymi instrumentami prawnymi jak policja. Z uwagi na powyższe, należy przyznać rację poglądowi konsekwentnie wyrażanemu przez Sąd Najwyższy w dotychczasowym orzecznictwie ${ }^{21}$, w którym nie podzielał on poglądów głoszonych przez niektórych przedstawicieli doktryny ${ }^{22}$, którzy wskazują, że z faktu,

18 Zob. A.R. Światłowski, Recenzja: D. Kala, Kodeksowe postępowania szczególne, Warszawa 2001, „Prokuratura i Prawo” 2001, nr 11, s. 137.

19 Zob. Z. Banasiak, Przyjęcie zawiadomienia o przestepstwie prywatnoskargowym w praktyce policyjnej, „Prokuratura i Prawo” 2010, nr 7/8, s. 229.

20 Ustawa z dnia 28 stycznia 2016 r. - Prawo o prokuraturze, Dz. U. z 2016 r. poz. 177 z późn. zm.

${ }_{21}$ W ten sposób m.in. Uchwała Sądu Najwyższego z dnia 15 kwietnia 1971 r., VI KZP 79/70, LEX nr 18234; Uchwała Sądu Najwyższego z dnia 20 kwietnia 1974 r., VI KZP 55/73, OSNKW 1974, nr 7-8, s. 128.

${ }_{22}$ W ten sposób m.in. M. Kulik, Przedawnienie karalności i przedawnienie wykonania kary w polskim prawie karnym, Warszawa 2014, s. 411; R. Kmiecik [w:] M. Jeż-Ludwichowska, A. Lach (red.), System Prawa Karnego Procesowego, t. 4. Dopuszczalność procesu, Warszawa 2015, s. 874-875. 
iż art. $488 \S 1$ k.p.k. nie stanowi wyraźnie o możliwości złożenia przez pokrzywdzonego skargi do prokuratora, należy wywodzić, iż pokrzywdzonemu takie uprawnienie $\mathrm{w}$ istocie nie przysługuje $\mathrm{i}$, tym samym, złożona przez niego do prokuratora skarga nie może być uznawana za wywołującą analogiczne skutki, jak skarga złożona na policji. Przyjęty w orzecznictwie Sądu Najwyższego sposób traktowania złożonej do prokuratora skargi prowadzić musi do wniosku, że w sytuacji, gdy pismo zawierające wyraźne żądanie wszczęcia postępowania karnego przeciwko osobie o czyn ścigany z oskarżenia prywatnego wpłynie do prokuratora, a ten nie zdecyduje się objąć tego czynu ściganiem z urzędu, powinien przekazać skargę sądowi właściwemu do rozpoznania sprawy ${ }^{23}$.

Skarga wskazana w art. 488 § 1 k.p.k. jest rodzajem skargi zasadniczej. Zawiera ona żądanie uprawnionego podmiotu, mającego w swym działaniu interes prawny, przeprowadzenia konkretnego rodzaju postępowania ${ }^{24}$. Trudno przyznać rację twierdzeniu D. Gila, który uważa, że skarga wniesiona przez policję w sprawie o przestępstwa prywatnoskargowe nie jest skargą uprawnionego oskarżyciela. Autor argumentuje swoje stanowisko brakiem ustawowego przyznania policji uprawnienia do ingerencji w postępowanie prywatnoskargowe (wskazując na wyłączność tej kompetencji dla prokuratora) oraz - przy skardze ustnej - działaniu policji niejako w charakterze pełnomocnika pokrzywdzonego, do czego również policja nie została ustawowo uprawniona, z uwagi na wyłączną kompetencję adwokata lub radcy prawnego w przedmiocie udzielania zastępstwa procesowego i sporządzania pism procesowych ${ }^{25}$. Wydaje się, że ten sposób postrzegania wszczęcia postępowania prywatnoskargowego w postaci złożenia ustnej lub pisemnej skargi na policji nie może zostać zaaprobowany. Przede wszystkim należy zauważyć, że rola policji może ograniczyć się do przyjęcia pisemnej skargi lub sporządzenia protokołu z przyjęcia skargi ustnej i przekazania skargi do właściwego sądu. Zabezpieczenie dowodów stanowi czynność fakultatywna, a o konieczności jej dokonania rozstrzyga sama policja (zezwala na to użyty w art. $488 \S 1$ k.p.k. zwrot „,w razie potrzeby" $)^{26}$. Ponadto, policja nie działa jako „pełnomocnik”, a jedynie przekazuje skargę do sądu. Jak zostało wskazane w orzecznictwie Sądu Najwyższego, w przypadku złożenia formalnie kompletnej skargi, do obowiązku policji należy wyłącznie prze-

23 Postanowienie Sądu Najwyższego z dnia 20 października 2016 r., III KK 212/16, „Prokuratura i Prawo”. (wkładka) 2016, nr 12, s. 14.

${ }_{24}$ Zob. T. Razowski, A. Tomaszewski, O właściwym rozumieniu skargi o wszczęcie postępowania $w$ sprawach o przestepstwa ścigane z oskarżenia prywatnego (art. 488 \& $1 \mathrm{KPK}$ ), „Prokuratura i Prawo" 2005, nr 6, s. 151-152.

${ }_{25}$ Zob. D. Gil, Postepowanie w sprawach z oskarżenia prywatnego w polskim procesie karnym, Warszawa 2011, s. 162.

26 Zob. Z. Banasiak, Przyjęcie..., s. 229-230. 
kazanie przyjętej skargi do sądu ${ }^{27}$. Nie ulega wątpliwości, że przyjęta i zaprotokołowana na żądanie pokrzywdzonego skarga, pozostaje nadal skargą pokrzywdzonego, a przekazanie jej do sądu stanowi jedynie urzeczywistnienie ustawowej procedury wszczęcia postępowania prywatnoskargowego. Możliwość złożenia ww. skargi niejako za pośrednictwem policji stanowi m.in. urzeczywistnienie prawa do sądu dla pokrzywdzonego, który nie jest $w$ stanie sporządzić samodzielnie prywatnego aktu oskarżenia, a nie korzysta z pomocy profesjonalnego pełnomocnika.

W doktrynie procesu karnego istnieją rozbieżności co do zakresu „zabezpieczenia dowodów” przez policję. Sprowadzają się one do odpowiedzi na pytanie, czy policja ma prawo podejmować czynności z własnej inicjatywy, co w konsekwencji może prowadzić do przekształcenia się podejmowanych przez nią czynności w „normalne” dochodzenie. Za przyjęciem takiej możliwości niewątpliwie przemawia fakt, że to i tak policja dokonuje oceny, czy dana czynność ma zostać przeprowadzona, czy nie. Ze względu na tak duży stopień decyzyjności mogłoby nie wydawać się nadużyciem umożliwienie organom ścigania podejmowania czynności z własnej inicjatywy. Ponadto, należy przedstawić argument, zgodnie z którym dla możliwości zabezpieczenia dowodu niezbędne jest jego wcześniejsze poszukiwanie, co daje policji pewną swobodę działania. Jednakże wydaje się, że taki pogląd jest zbyt daleko idący, zwłaszcza w stosunku do sformułowania użytego przez ustawodawcę. Wydaje się, że kładąc nacisk tylko na jeden z elementów postępowania dowodowego (zabezpieczenie dowodów) ustawodawca nadał policji uprawnienie jedynie do utrwalenia dowodów i zabezpieczenia ich przed zniszczeniem, utratą lub zniekształceniem. Argumentem za przyjęciem takiego rozwiązania jest zamieszczone $\mathrm{w}$ art. $488 \S 2$ k.p.k. (dotyczącym czynności dochodzeniowo-śledczych policji wykonywanych na polecenie sądu) odwołania do postępowania $\mathrm{w}$ niezbędnym zakresie. Co prawda expressis verbis nie istnieje takie odesłanie dla czynności policji podejmowanych po przyjęciu skargi, jednakże, ze względu na podobieństwo tych instytucji, ograniczenie kompetencji policji do czynności wskazanych w art. 308 § 1 k.p.k. wydaje się zasadne ${ }^{28}$. Także w tym miejscu nie wolno zapominać o wiodącej roli pokrzywdzonego w postępowaniu prywatnoskargowym - to właśnie inicjatywa tego podmiotu powinna mieć pierwszoplanowe znaczenie dla czynności podejmowanych $\mathrm{w}$ postępowaniu. Założeniem postępowania $\mathrm{w}$ sprawach z oskarżenia prywatnego jest przeniesienie pewnych obowiązków z organów ścigania właśnie na pokrzywdzonego, a w związku z tym, nawet, jeżeli usta-

27 Wyrok Sądu Najwyższego z dnia 1 marca 2013 r., III KK 218/12, „Prokuratura i Prawo" (wkładka) 2013, nr 6, s. 28.

${ }_{28}$ Zob. K. Dudka, Wybrane problemy dochodzenia w sprawach o przestepstwa prywatnoskargowe, „Prokuratura i Prawo" 2005, nr 6, s. 34-35. 
wa dopuszcza te organy do udziału w postępowaniu, to ich rola powinna zostać ograniczona do niezbędnego minimum. Należy w tym miejscu zauważyć, że opisywany zakres czynności policji odnosi się przede wszystkim do postępowania dowodowego i - jak zostało już wskazane powyżej - swego rodzaju rozszerzeniem kompetencji policji jest podjęcie czynności służących dookreśleniu oskarżonego, co jest uwarunkowane umożliwieniem faktycznego wszczęcia postępowania prywatnoskargowego.

Istotnym zagadnieniem jest także zróżnicowanie skargi wszczynającej postępowanie prywatnoskargowe od złożenia zawiadomienia o przestępstwie. Podejmując analizę powyższego zagadnienia od strony teoretycznej można zauważyć znaczące różnice. Zawiadomienie o możliwości popełnienia przestępstwa jest oświadczeniem wiedzy osoby je składającej. Jego nadrzędną funkcją jest przekazanie informacji organom ścigania na temat określonego zdarzenia, które może wypełniać znamiona konkretnego typu czynu zabronionego, co więcej, przekazanie jej w sposób dający podstawę do oceny zasadności przedstawionej informacji (spowodowania uzasadnionego podejrzenia możliwości popełnienia przestępstwa z art. 303 k.p.k.). Skutkiem złożenia zawiadomienia o przestępstwie jest zasadniczo wszczęcie lub odmowa wszczęcia przygotowawczego stadium procesu karnego. Zgoła odmiennie przedstawia się charakterystyka skargi o wszczęcie postępowania prywatnoskargowego. Stanowi ona przede wszystkim oświadczenie woli pokrzywdzonego, postulujące wszczęcie postępowania sądowego, a jedynie $\mathrm{w}$ razie potrzeby uaktywnienie policji w zakresie wskazanym w skardze. Co istotne, policja nie ocenia zasadności skargi. Zawierające się w skardze oświadczenie wiedzy pokrzywdzonego na temat określonego stanu faktycznego stanowi jedynie podstawę dla oświadczenia woli o pociągnięciu określonej osoby do odpowiedzialności karnej, nie jest zatem istotą skargi. Następstwem jej skutecznego wniesienia jest wszczęcie postępowania jurysdykcyjnego, nie przygotowawczego, jak w przypadku zawiadomienia o przestępstwie ${ }^{29}$.

\section{Wszczęcie postępowania prywatnoskargowego przez prokuratora}

Założeniem leżącym u podstaw powstania niniejszego tekstu było spojrzenie na proces inicjowania postępowania prywatnoskargowego z perspektywy dominus litis tego postępowania, a więc pokrzywdzonego.

${ }^{29}$ Zob. E. Kruk, Skarga.., s. 81-82. 
Dlatego też jedynie sygnalizacyjnie należy wskazać, że na podstawie art. $60 \S 1$ k.p.k. kompetencję do wszczęcia postępowania prywatnoskargowego posiada również prokurator. Przesłankę ingerencji prokuratora w postępowanie w sprawach $\mathrm{z}$ oskarżenia prywatnego stanowi interes społeczny, a z chwilą wszczęcia toczy się ono w trybie publicznoskargowym. Już na wstępie należy podkreślić, że w przedmiotowym układzie procesowym pokrzywdzony ma uprawienia ku temu, aby aktywnie działać w procesie. Na podstawie art. $54 \S 1$ k.p.k. w zw. z art. $60 \S 2$ k.p.k. może stać się oskarżycielem posiłkowym ubocznym, o ile w terminie, tj. do rozpoczęcia przewodu sądowego na rozprawie głównej, złoży stosowne oświadczenie.

Wszczęcie postępowania prywatnoskargowego przez prokuratora może przybrać różne formy. Jedną z nich jest wszczęcie w formie prostej, wyraźnej, a więc przez wydanie postanowienia o wszczęciu dochodzenia (w wyjątkowych wypadkach śledztwa). Wyrazem wszczęcia postępowania o czyn prywatnoskargowy może być również wniesienie aktu oskarżenia do sądu. W ten sposób prokurator wyraża nie tylko swoją wolę do realizacji uprawnienia przewidzianego w art. 60 § 1 k.p.k., lecz faktycznie dokonuje wszczęcia tego postępowania. Zaznaczył to Sąd Apelacyjny we Wrocławiu, dodając jednocześnie, że wskazane jest, aby prokurator taką decyzję poprzedził wydaniem postanowienia, lecz nie jest to warunek konieczny ${ }^{30}$.

Przesłanką ingerencji prokuratora w postępowanie prywatnoskargowe jest interes społeczny. Warto zauważyć, że interes społeczny jest kategorią obiektywną i nie zależy od niczyjego uznania - prokurator ingerujący w postępowanie prywatnoskargowe jedynie stwierdza jego istnienie ${ }^{31}$. Jednocześnie art. 60 § 1 k.p.k. obliguje prokuratora do wszczęcia lub wstąpienia do postępowania $\mathrm{w}$ przypadku zaistnienia interesu społecznego. Obowiązek prokuratora wynika z wykładni gramatycznej przytoczonego przepisu, zgodnie z którym prokurator wszczyna lub wstępuje do postępowania, jeżeli wymaga tego interes społeczny. Na obligatoryjność ingerencji prokuratora wskazuje stanowcza forma użytego przez ustawodawcę czasownika. Jednakże należy w tym miejscu zauważyć, że to prokurator stwierdza istnienie interesu społecznego, co czyni wskazany obowiązek względnym, ponieważ to sam prokurator, przez stwierdzenie interesu społecznego, nakłada go na siebie. W związku z tym, wykluczona jest jedynie sytuacja procesowa, w której prokurator stwierdzi istnienie interesu społecznego i nie podejmie ingerencji w postępowanie.

30 Wyrok Sądu Apelacyjnego we Wrocławiu z dnia 24 maja 2012 r., II AKa 130/12.

31 Zob. K. Dudka, M. Mozgawa, Ingerencja prokuratora $w$ ściganie przestęs stw prywatnoskargowych, [w:] A. Siemaszko (red.), Stosowanie prawa. Księa jubileuszowa z okazji XX-lecia Instytutu Wymiaru Sprawiedliwości, Warszawa 2011, s. 450. 
Brak zgody pokrzywdzonego na objęcie ściganiem czynu prywatnoskargowego nie stanowi przeszkody dla wykonania przez prokuratora jego uprawnień. Jeżeli ewentualny sprzeciw pokrzywdzonego został wyrażony już po zrealizowaniu się znamion przestępstwa, pozostaje on bezskuteczny, ponieważ prokurator jest związany jedynie zaistnieniem przestępstwa. Późniejszy sprzeciw pokrzywdzonego nie ma znaczenia dla materialnoprawnej oceny czynu stanowiącego przestępstwo, a więc nie wywołuje skutków prawnych względem praw i obowiązków prokuratora. Zgoda (lub jej brak) na objęcie ściganiem czynu prywatnoskargowego przez prokuratora nie jest tożsama ze zgodą na naruszenie dóbr prawnych pokrzywdzonego. Jeżeli w momencie popełnienia czynu zabronionego została przez pokrzywdzonego wyrażona zgoda na naruszenie jego dóbr chronionych normami prawa karnego, to jednocześnie następuje kontratypizacja takiego zachowania. W związku z urzeczywistnieniem się kontratypu nie dochodzi do popełnienia przestępstwa, a więc jednocześnie prokurator nie nabywa uprawnienia do podjęcia działań przewidzianych w art. 60 k.p.k. ${ }^{32}$

\section{Podsumowanie}

Postępowanie prywatnoskargowe to postępowanie szczególne, którego założeniem jest przekazanie w ręce pokrzywdzonego wszczęcia i prowadzenia tego postępowania, co uwarunkowane jest zakreśleniem przez ustawodawcę takich typów czynów zabronionych, do których stosuje się przepisy o przedmiotowym postępowaniu, które odnoszą się w szczególności do naruszenia interesu prywatnego pokrzywdzonego. $Z$ uwagi na konieczność wszczęcia tego postępowania praktycznie bez udziału organów powołanych do ścigania przestępstw w myśl kodeksowej zasady legalizmu, właściwe jego wszczęcie, a więc skuteczne wniesienie prywatnego aktu oskarżenia do sądu lub właściwe złożenie ustnej lub pisemnej skargi na policji, stanowi element postępowania warunkujący możliwość pociągnięcia sprawy przestępstwa prywatnoskargowego do odpowiedzialności karnej. Ustawodawca uprościł wskazaną procedurę do wymogów stanowiących $\mathrm{w}$ procesie karnym niezbędne minimum, co nie powoduje jednak braku problemów w praktyce jej stosowania. Jednakże znaczenie praktyczne skutecznego wszczęcia postępowania prywatnoskargowego jest zagadnieniem bardzo istotnym, bowiem powołując się na dane staty-

${ }^{32}$ Zob. P. Daniluk, Zgoda uprawnionego a tryb ścigania, „Przegląd Sądowy” 2005, nr 5, s. 130. 
styczne ${ }^{33} \mathrm{~W}$ sądach rejonowych rokrocznie toczy się około dwudziestu tysięcy spraw ściganych z oskarżenia prywatnego, w tym w około ośmiu tysiącach spraw zapadają orzeczenia pierwszoinstancyjne.

Słowa kluczowe: postępowanie prywatnoskargowe, wszczęcie postępowania, prywatny akt oskarżenia, skarga na policji

\section{Bibliografia}

\section{Źródła}

\section{Akty prawne}

Konstytucja RP z dnia 2 kwietnia 1997 r., Dz. U. z 1997 r. Nr 78, poz. 483 z późn. zm.

Ustawa z dnia 6 czerwca 1997 r. - Kodeks postępowania karnego, Dz. U. Nr 89, poz. $555 \mathrm{z}$ późn. $z \mathrm{zm}$.

Ustawa z dnia 28 stycznia 2016 r. - Prawo o prokuraturze, Dz. U. z 2016 r. poz. 177 z późn. zm.

Rozporządzenie Ministra Sprawiedliwości z dnia 28 maja 2003 r. w sprawie wysokości zryczałtowanej równowartości wydatków w sprawach z oskarżenia prywatnego, Dz. U. z 2003 r. Nr 104, poz. 980.

\section{Orzecznictwo}

Postanowienie Sądu Najwyższego z dnia 20 października 2016 r., III KK 212/16, „Prokuratura i Prawo” (wkładka) 2016, nr 12, s. 14.

Postanowienie Sądu Najwyższego z dnia 31 marca 2015 r., IV KK 3/15, LEX nr 1666903.

Postanowienie Sądu Najwyższego z dnia 21 stycznia 2015 r., V KK 297/14, LEX nr 1652419.

Wyrok Sądu Najwyższego z dnia 1 marca 2013 r., III KK 218/12, „Prokuratura i Prawo" (wkładka) 2013, nr 6, s. 28.

Uchwała Sądu Najwyższego z dnia 30 września 2010 r., I KZP 10/10, OSNWK 2010, nr 10, poz. 84.

Postanowienie Sądu Najwyższego z dnia 20 lipca 2005 r., I KZP 22/05, OSNKW 2005, nr 9, poz. 73.

Postanowienie Sądu Najwyższego z dnia 17 kwietnia 1997 r., I KZP 4/97, Wokanda 1998, nr 1, s. 16.

Uchwała Sądu Najwyższego z dnia 20 kwietnia 1974 r., VI KZP 55/73, OSNKW 1974, nr 7/8, s. 128.

Uchwała Sądu Najwyższego z dnia 15 kwietnia 1971 r., VI KZP 79/70, LEX nr 18234.

33 Zob. Rocznik Statystyczny Rzeczypospolitej Polskiej, wyd. GUS, Warszawa 2017, s. 162 i 172. 
Wyrok Sądu Apelacyjnego we Wrocławiu z dnia 24 maja 2012 r., II AKa 130/12. Postanowienie Sądu Apelacyjnego w Lublinie z dnia 28 lipca 1999 r., II AKz 181/99. Postanowienie Sądu Okręgowego w Tarnowie z dnia 2 sierpnia 2005 r., II Kz 157/05, KZS 2005, z. 9, poz. 63.

Postanowienie Sądu Okręgowego w Tarnowie z dnia 2 października 2007 r., II Kz 232/07, KZS 2007, z. 11, poz. 74.

\section{Literatura}

Banasiak Z., Przyjęcie zawiadomienia o przestępstwie prywatnoskargowym w praktyce policyjnej, „Prokuratura i Prawo” 2010, nr 7/8, s. 222-239.

Daniluk P., Zgoda uprawnionego a tryb ścigania, „Przegląd Sądowy” 2005, nr 5, s. 130-143.

Dudka K., Wybrane problemy dochodzenia w sprawach o przestęstwa prywatnoskargowe, „Prokuratura i Prawo” 2005, nr 6, s. 32-37.

Eichstaedt K., Postępowania szczególne w polskim procesie karnym, Warszawa 2010.

Gil D., Postępowanie w sprawach z oskarżenia prywatnego w polskim procesie karnym, Warszawa 2011.

Gostyński Z. (red.), Kodeks postępowania karnego. Komentarz, t. 3, Warszawa 2004.

Grajewski J., S. Steinborn, Komentarz aktualizowany do art. 487 Kodeksu postępowania karnego, LEX nr 470173.

Grzegorczyk T., Kodeks postępowania karnego. Komentarz, Kraków 2005.

Grzegorczyk T., Komentarz do art. 487 Kodeksu postępowania karnego, LEX nr 70359.

Jeż-Ludwichowska M., A. Lach (red.), System Prawa Karnego Procesowego, t. 4. Dopuszczalność procesu, Warszawa 2015.

Kulik M., Przedawnienie karalności i przedawnienie wykonania kary w polskim prawie karnym, Warszawa 2014.

Kruk E., Skarga w postępowaniu prywatnoskargowym, „Ius Novum” 2012, nr 4, s. 78-92.

Razowski T., A. Tomaszewski, O właściwym rozumieniu skargi o wszczęcie postępowania w sprawach o przestępstwa ścigane z oskarżenia prywatnego (art. 488 § 1 KPK), „Prokuratura i Prawo” 2005, nr 6, s. 151-158.

Rocznik Statystyczny Rzeczypospolitej Polskiej, wyd. GUS, Warszawa 2017.

Sakowicz A. (red.), Kodeks postępowania karnego. Komentarz, Warszawa 2016.

Siemaszko A. (red.), Stosowanie prawa. Ksiega jubileuszowa z okazji XX-lecia Instytutu Wymiaru Sprawiedliwości, Warszawa 2011.

Stefański R.A., Komentarz do art. 487 Kodeksu postępowania karnego, t. 1, LEX nr 69644.

Stefański R.A., Odpowiedź na akt oskarżenia, „Prokuratura i Prawo” 2005, nr 5, s. 43-49.

Światłowski A.R., Recenzja: D. Kala, Kodeksowe postępowania szczególne, Warszawa 2001, „Prokuratura i Prawo” 2001, nr 11, s. 135-138.

Świecki D. (red.), Kodeks postępowania karnego. Tom II. Komentarz aktualizowany, LEX/ el 2018. 


\section{METHODS OF INITIATING PRIVATE PROSECUTION PROCEEDING}

\section{S u m m a $\mathbf{r} \mathbf{y}$}

In view of the need to achieve the objective of the criminal proceeding in the form of the need to terminate the proceedings within a reasonable time, it would seem reasonable to use the institution of simplified forms of criminal responsibility, including special proceedings. This article presents two options for initiating private prosecution proceeding, namely private indictment and oral or written complaint filed with the Police. The author presents problems of both - factual and legal - nature, taking into account the possibility of their practical application.

Key words: private prosecution proceeding, initiation of proceeding, private indictment, complaint at the Police

\section{СПОСОБЫ ВОЗБУЖДЕНИЯ ПРОИЗВОДСТВА ЧАСТНОГО ОБВИНЕНИЯ}

$$
\text { P e } 3 \text { ю м е }
$$

В связи с необходимостью реализации цели уголовного процесса в виде необходимости окончания производства в разумный срок, принципиально, кажется, быть возможно как самое частое применение учреждения касательно упрощенных форм вынесения решений об уголовной ответственности, вкдючая положений об особенных производствах. Данный текст содержит исследования двух возможностей возбуждения производства частного обвинения, а именно частного акта обвинения и устной дибо письменной жалобы, которая скдадывается в Подиции. Автор представляет проблемы, как фактической природы, так и юридической, с учетом их возможности практического применения.

Кдючевые слова: производство частного обвинения, возбуждения производства, частный акт обвинения, жалоба в Полиции 